\title{
College Librarians and Recruiting
}

Mr. Harvey is librarian, Kansas State Teachers College, Pittsburg.

$\mathrm{R}^{\mathrm{k}}$ ECRUITING IS A popular subject. Ever since the great shortage of librarians developed during the last war, we have been talking about it. College and university librarians should join the movement to recruit more and better librarians for the library schools. This is necessary because of the present shortage, and because college librarians are in a good position to recruit.

To have vacancies seems to be chronic. It is unusual for a college or university library director to fill his vacancies easily. The library school deans would like to help, but they often have no names in their files. These vacancies are especially numerous for positions with specialized qualifications. Try to find a good chemistry librarian, agriculture librarian, physics librarian, art librarian, or catalog librarian! The library schools do not graduate enough people to fill all these vacancies; most library schools are small and struggling and are operating well below capacity, as they have for several years.

Everyone talks about the personnel shortage, but few librarians do anything about it. The library school deans expect their alumni to recruit, but the alumni leave it to the deans. The profession expects the Joint Committee on Library Work as a Career to direct national recruiting, but the Joint Committee waits for the profession to recruit. It is time we stopped buck-passing, and began recruiting seriously.

College librarians are in a good position to recruit. School librarians, because of their association with high school student assistants about to make vocational decisions, should also recruit; but college librarians have several advantages over them.

In the first place, college and university librarians also work with student assistants -our most promising recruits. Many staff members work closely with them and have good opportunities for recruiting. Often student assistants are given some responsibility and do work of near-professional quality. Inevitably, they must learn much about library work, and should be easily sold on it. College librarians can also identify those students interested in reading and in books, and they should also be good prospects.

I have urged school librarians to recruit because many vocational decisions are made in high school ; many students arrive at college with a major and a career already chosen. But it is also true that many others have not yet decided. In the liberal arts colleges, especially, we find many students who have not yet made vocational decisions, and they may well listen to our discussion of librarianship.

There are also college students who have chosen a major but have no post-graduation plans. In many fields, to pursue the major field after graduation, the student must teach, and many students do not care to teach. By all means, these students should receive our close attention. Librarianship needs people with varied backgrounds; we need people from every major field to serve in our many departmental libraries. Where are we to find the chemistry, agriculture, physics, art, and catalog librarians unless we persuade majors in these departments to become librarians? 
College and university librarians have yet another advantage over school librarians. Most school libraries are small with only a few thousand volumes, while college libraries are much larger. Some are large institutions in their own right with hundreds of staff members. College library student assistants see much larger and more interesting and impressive libraries than do high school library student assistants. And they see full-time professional librarians giving good service, while high school students sometimes see a part-time librarian with little library education giving inadequate service. College students can see librarians in many different types of positions, while high school students see only one librarian, so they cannot appreciate the variety of jobs possible in the profession. All of this should make recruiting easier for the college librarian.
College librarians also work with students who are nearing maturity. They can guess more accurately how these students will turn out-how promising they arethan can high school librarians. They can predict with more accuracy how good these students would be as librarians.

College students are soon to be wageearners, so vocational choices are more important to them. High school students can postpone their decisions several years, but time is more pressing for college students. This should make them more serious, of course. Delivering the goods to library school should be easier when the students are only one instead of five years away.

College librarians, therefore, should be among our most successful recruiters; they have many advantages over other librarians. They must recruit in every library or our personnel shortage will continue.

\section{A Unique Friends of the Library Group}

\section{(Continued from page 367)}

annual dues-which is interpreted as "buying a book for Brandeis"-is new. Possibly we found ourselves in a position to take advantage of a pattern of community organization established and ingrained into the Jewish communities of the country by other Jewish philanthropies such as Hadassah, and such a pattern would not be generally available to other institutions. Very probably the unique quality of Brandeis as a non-sectarian university sponsored by the Jewish people triggered a wave of support and enthusiasm which would be difficult to generate for a university with generations behind it. If such is the case, the real test of our Friends movement will come when we have at least decades, if not generations, behind us. Nevertheless, for those librarians who have felt that their administrations are somewhat lukewarm in their support of their efforts to develop a Friends movement, it would seem as if this report could be of assistance as an indication of what may result trom a concerted and sustained effort which involves all elements of the university.

\section{Eastern College Conference}

The forty-first conference of the Eastern College Librarians will be held on Saturday, November 26, 1955, in McMillin Theater of Columbia University. The morning meeting will be devoted to "Recruiting Library Personnel" and the afternoon meeting to "Automation in the Library." A copy of the program will be mailed upon request to the chairman, Lorena A. Garloch, university librarian, University of Pittsburgh. 